of scarlet fever began to appear in the town, and between that date and December of that year 52 scarlet fever patients had been removed to the hospital as the result of this Act. They had been removed from 44 houses, some containing more than one family, and in those houses there were 101 children who had not had scarlet fever, yet in only one house did a second attack oceur, this result being attained by the fact that notification led to immediate removal.

Now come we to Dr. Thorne Thorne's recantation. On March 24th, 1882 Question 5321, we find the Chairman asking: "I believe you wish to make some qualification of the evidence you gave upon a former occasion?"

Dr. Thorne Thorne: Yes. Referring to my evidence given in January last as to the measures taken at Leicester and Warrington I have thought it right to add some more recent evidence. ..... I feel that the evidence I gave as regards Leicester and Warrington is open to the inference
that in those boroughs the joint operation of a system for the comthat in those boroughs the joint operation of a system for the com-
pulsory notification of infectious diseases and the provision of pulsory notification of infectious diseases and the provision of check the spread of scarlet fever. More recent informacheck the spread of scarlet fever. More recent information does not, in my opinion, bear out that view to the extent
I had anticipated. As regards Leicester, for example, a diminished scarlet fever mortality during the epidemic prevalence of 1879 was compared with that occurring during similar epidemics in 1870 and 1875, but the returns of the Registrır General for 1880 and 1881 point out that, notwithstanding the joint operation, since September, 1879, of a system for the notification of infectious diseases, and of a hospital for their isolation, there has been a very long continued prevalence of scarlet fever, and when the whole period of the latter prevalence is compared with that of the two former ones it would appear that the later epidemic has mainly differed from its predecessors by being spread over a longer period. Then the other instance was the case of Warrington. When I was in Warrington in 1881 I found that the epidemic appeared to have been all but checked, there being only three, four, and three cases of scarlet fever respectively admitted to hospital during the months of January, February, and March, 1881, and only four, four, and three cases notified in the borough during those several months. Since then, however. there has been a marked increase in the disease. I felt that this result did not bear out the inference which might be drawn from my previous evidence.

Question 5323: Are you aware of any sufficient reason why scarlet fever should have increased?

Dr. THORNE THORNE : NO

Dr. Car penter: I should like to ask if notification was carried out in Warrington to its full extent?-It would be difficult to find any place where ntification had been so effectually carried out.

Question 5329: Notification has failed to "stamp out" disease at arrington?-Yes.

On March 21st was taken the evidence of Mr. George W. Hastings, M.P., whose Bill, as I have already said, was then before the House of Commons.

Question 5112 (Dr. Carpenter): You believe that notification is required for the purpose of repressing and "stamping out" infectious diseases?

Mr. H.astings : Yes.

It is perfectly evident, then, that "stamping out" was the end and aim of those who originated this movement, and the idea that infectious diseases could and would be "stamped ont" by such means was held largely notwithstanding the fact that there were nos only no data to go upon but all previous experience (e.g., the prevalence in many hospitals of hospital gangrene) puinted to the fact that the aggregation of the sick-infective and other-was a mistake.

You make me say, Sirs, that "vital statistics are the third degree of comparison of unveracity." I respectfully point out that I neither said this nor anything like it. What I did say was that these were the only statistics upon which any sor 0 of reliance could be placed. Like Mr. Jonathan Hutchinson "I distrust all statistics-no one more than I." I am not going to traverse the statement quoted from Whitelegge's book. Any man who knows and has worked with Dr. Whitelegge as I have would think twice before he tried to controvert his carefully collected facts. That "epidemics occur at more or less irregular intervals in most of the large towas" cannot, I submit, be received as a satisfactory explanation as to why preventive institutions when dealing with an infective disease each case of which can only have arisen from a previously existing case are impotent in the discharge of the fanctions for which they were established, even when isolating 90 per cent. of the cases.

You accuse me, Sirs, of changing my ground. Not so. If you hold that, before condemning these institutions in toto I ought to have backed up my condemnation by the publication of data, I shall cry peccavi. I hope shortly to bring before the profession the question as to what has been the effect on diphtheria of "isolation." I shall show that if hospitalism has blocked the way of sanitary progress so far as scarlet fever is concerned its effect has been infinitely worse in the case of diphtheria. I shall endeavour to prove that the way to prevent disease does not lie in the direction of aggregating the diseased. Sirs, the isolation hospital is the record achievement of misdirected effort in our time. To my certain knowledge this fact is known and recognised by many who are in the public health service. Why have so few the courage of their convictions? In what danger from what quarter does a man stand for the fearless expression of his opinions? What is the mystery?

Your readers will be interested, Sirs, in learning what views are beginning to prevail in Germany on this important question. The distinguished writer, Hueppe, hits off the situation admirably when he says (speaking of the central authority): "Instead of being always prepared to act in the spirit of preventive hygiene for the most part plods on in the good old way with "fresh emendations to the appendix of the modified supplement of the most recent provisional administrative instructions." I give the views of this distinguished bacteriologist with the more pleasure because isolation hospitals had their inception in a crude and unscientific conception of the lessons to be learned from discoveries which had been made in the field of bacteriological research during the Pasteur-Tyndall-Miguel epoch. The sanitarian, impatient of tried methods-which, by-thebye, had by no means been found wanting -and always on the qui vive for short cuts to the accomplishment of the ends he had in view, imagined that the royal road to disease prevention ran through that inex'ricabilis error which the bacteriologist had prepared for the medical scientist to wander in and get lost. Hueppe, in the last edition of his "Principles of Bacteriology," 1899 , claims that the way to prevent the dissemination of disease germs is by improvement in the water and soil, control of the food-supply, and works of sanitation generally.

"Works of sanitation," says this writer, "act upon saprophytes and interfere with the dangerous forms of proteid pntrefaction which play a rôle in intoxications and are of importance in the ontogeny and phylogeny of parasites. ......Again, in the separation of the sick from the healthy we often overshoot the mark and the compulsory conveyance of the sick from the dwelling-place to the hospital is frequently very injurious. ..... The psychic disadvantages, also, are frequently quite considerable, and the abolition of humanity by bacteriology seems to me a step backwards. ..... Cholera convalescents, even after they have perfectly regained their health, may harbour germs for weeks ...... diphtheria convales cents may carry about bacilli for months. On this account compulsory isolation upon the basis of bacteriological findings may lead to the greatest injury. .... The imprisonment of healthy and convalescent individuals is an inadmissible restriction of personal freedom. ..... In diseases, too, of the character of scarlet fever we have, to the delight
of martinets, done too much in the last decade in the matter of isolation. ...... The prevention of infective diseases is to be attained by comtion. ..... The prevention of infect

In conclusion, Sirs, let our friends of the public health profession be certain that the value of these institutions is being appraised by the intelligent section of the British public and it is a force they will not be able to resist. The individualist has been long weary of the sacrifice of the individual for the questionable good of the rest. The economist, who sees in an institution like ours a threepenny rate with no equivalent advantages, is fretting under the imposition of useless burdens, while the politician is standing aghast at the enormous growth of the municipal debt of this country in which he sees the setting in of the rot in our commercial prosperity.

Nottingham. I am, Sirs, yours faithfully

* We publish Mr. Marriott's lengthy because we feel it incumbent upon us to afford him an opportunity of replying to a leading article largely dealing with his views, but we do not see that he introduces any new matter quite pertinent to the controversy. He does not refer us to any memorandum of the Local Government Board which would justify the importance which he has attached to the stamping out thesis. He disclaims having written that "vital statistics are the third degree of comparison of unveracity." We refer him to the bottom of page 19 of a pamphlet which he sent us. He will there find these words, "Statistics are being pressed into the service-statistics which are notoriously the third degree of comparison of unveracity."-ED. L.

\section{THE LIFE-SAVING STATION AT WATERLOO BRIDGE.}

\section{To the Editors of THE LANCET.}

SIRS, - In the year 1872, at my suggestion, the Royal Humane Society established this station and appointed me medical officer thereto. About two years subsequently the station was, by arrangement, handed over to the Thames 
Police, whose floating station was near at hand, and I was succeeded by the then divisional surgeon, Mr. Mills, of Southampton-street, Strand. I now, with much pleasure, inclose you a "return" from the superintendent of the Thames Police, showing the excellent work the station has done during the years it has been established. Having regard to the great number of suicidal and accidental drownings annually occurring in other parts of the Thames-notably Battersea, Putney, Hammersmith, \&c.-I would ask you to urge the further provision of similar institutions at other parts of the river in the metropolitan area.-I am, Sirs, yours faithfully,

ARCHER FARR. L.R.U.P., L.S.A., \&c., Late Medieal Officer of Health, Lambeth,

High-street, Putney, S.W., Feb. 21st, 1901. [INCLOSURF.]

THAMES Division.

Return of the Number of Cases Treated at Waterloo Pier Station during the Fears 1897-8-9 (Vide Corr. No. 322034).

\begin{tabular}{|c|c|c|c|c|c|c|}
\hline \multicolumn{2}{|r|}{ Year. } & 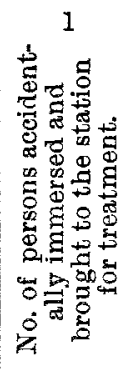 & 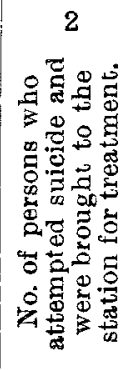 & 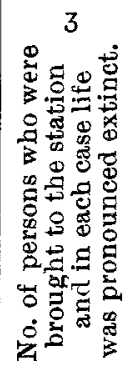 & 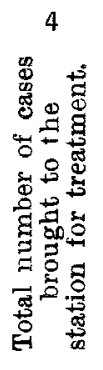 & 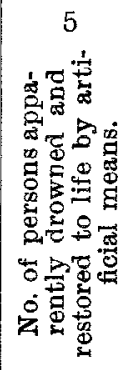 \\
\hline 1897 & $\begin{array}{lll}\ldots & \ldots & \ldots\end{array}$ & 8 & 22 & 10 & 40 & 1 \\
\hline 1898 & $\begin{array}{lll}\cdots & \cdots & \cdots\end{array}$ & 8 & 16 & 5 & 29 & - \\
\hline 1899 & $\begin{array}{lll}\cdots & \cdots & \cdots\end{array}$ & 7 & 13 & 16 & 36 & - \\
\hline $\begin{array}{r}\text { Total } \\
\text { yea }\end{array}$ & $\left.\begin{array}{cc}\text { for } & \text { three } \\
\mathrm{s} & \ldots\end{array}\right\}$ & 23 & 51 & 31 & 105 & 1 \\
\hline
\end{tabular}

In a number of cases which cannot be included in column 5, "apparently drowned and restor ed to life," as there were evident signs of vitality, the sufferer would probably have succumbed to shock and immersion but for the prompt treatment by police. It is not possible to give the number of these cases from the records with accuracy.to give the number of these cases
WM. C. RoBINsoN, Superintendent.

\section{"CONCERNING CERTAIN APPARENTLY INJURIOUS CONSTITUENTS OF POTABLE SPIRITS." \\ To the Editors of THE LANCET.}

SiRs, - In an article by us in THE LANCeT of Dec. 8th, 1900 , p. 1643, under the above title the statement occurs that "we made experiments upon cats, dogs, and rabbits." This statement we wish to correct in that our own experiments were only made upon cats and dogs. At the time of writing we had really in our minds not only our own experiments but those of a previous worker-viz., Cohn. ${ }^{1}$ Our paper was intended only as a preliminary communication and experimental details will be given fully and compared with the results of others in a subsequent paper.

We are, Sirs, yours faithfully,

LAUDER BRUNTON.

F. W. TUNNICLIFFE.

Devonshire-street, Portland-place, W., Feb. 25th, 1901.

\section{THE COVENTRY DISPENSARY. \\ To the Editors of THH LANCET.}

SIRS,-In THE LANCET of Feb. 2nd, p. 353, under the head of "The Battle of the Clubs," there are some remarks concerning the Coventry Dispensary which the staff will be glad if you will allow them to correct. It is untrue that the reply which the staff received to their memorial was that "if they were not satisfied with their position another staff could be procured to take their places." Nothing whatever was said in the reply which could be thas construed. It is also untrue that the committee do "not hand over all the

1 Archiv für Experimentelle Pathologie und Pharmakologie, vol. xxxi., p. 40. money received and thus $\epsilon$ xploited them" (the staff). All the money is divided amongst the staff after the working expenses have been paid. The number present at the meeting was 108 , not 160 , and so far from being unanimous there was a very large proportion who refrained from voting either for or against the resolution.

I am, Sirs, yours faithfully,

W. J. PICKUP,

For the Stafe of the Coventry Dispensary.

Swansw ell, Coventry, Feb. 23rd, 1901

\section{MEMORIAL TO THE LATE PROFESSOR TOM JONES. \\ To the Editors of THW LANOET.}

SIRS,-It is proposed to establish some memorial of Professor T. Jones in the Owens College, and it is thought that his personal friends, and perhaps others, may wish to take part in providing the necessary funds.

No appeal will be made, out the treasurer or secretaries will be glad to receive contributions from those who desire to honour Professor Jones's memory.

The exact form the memorial will take necessarily cannot be settled till the amount of the fund is known, but it has been suggested that an exhibition or prize would be a suitable record of Mr. Jones's work.

It is not desired to limit in any way the amount of individual subscriptions, and it is hoped that those who may see this letter will bring it to the notice of other friends.

Subscriptions may be sent to either the honorary treasurer or the honorary secretaries.

Among the amounts already promised are the following:-

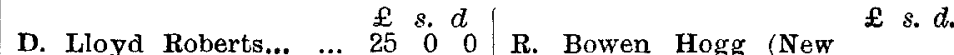
Walter Whitehęad....

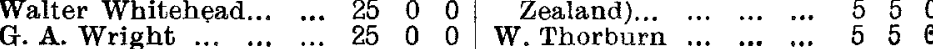

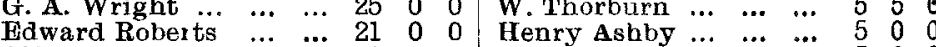

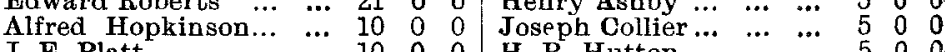

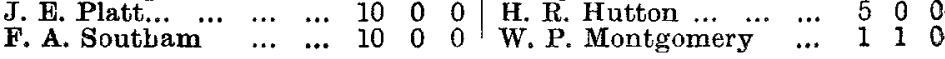

The complete total promised is over $£ 600$.

We are, Sirs, yours faithfully, HENRY ASHBY. JOSEPH COLLIER.

D. LLOYD ROBERTS, EDWARD ROBERTS

ALFRED HOPKINSON, ALFRED SIMPSON. K.0. F. A. SOUTHAM. A. MCLaren. JOHN D. MILNE. W. THORBURN. W. P. MONTGOMERY. A. H. YOUNG. G. A. WRIGHT, Hon. Treasurer 16, st. John-street, Manchester.
J. E. PLATT,

14, St. John-street, Manchester. January, 1901. H. CoutTs, \}$\underset{\text { Hon. }}{\text { Secretaries. }}$

\section{"THE TEACHING OF AN ASSTHETICS." To the Editors of THE LANCET.}

SrRs,-Dr. Frederic Hewitt's letter in THE LANCET of Jan. 19th, p. 212, in reply to that of LientenantColonel E. Lawrie in the number of Jan. 5th, p. 64, is chiefly characterised by the fact that it is in no way the answer it purports to be. If I may venture to sum up the letters it would be in some such way as this. Lientenant-Colonel Lawrie says essentially that chloroform administered in a defivite way may be given with safety by the ordinary man; while Dr. Hewitt says that chloroform as given in Britain by the orc inary man is very fatal (an undoubted fact, but scarcely an answer), and he hints that this is the effect of climate and not of the method of administration-or, at least, that is what I take his reference to "sunny Hyderabad" to mean. The intention of this letter is to lay stress on Lieutenant-Colonel Lawrie's statement that the $\epsilon$ ffect of the London teaching is to tend to make the anæsthetist incompetent through fright, for I can testify from personal experience as well as from personal observation of the terror with which many recently qualified men in London approach the administration of chloroform, believing as they do that death may occur suddenly and inexplicably from syncope. My own experience was distressing until I realised that if chloroform could be given in India and in Edinburgh with confidence and safety by using a particular 